\title{
Genetically-engineered Immune Cell
}

National Cancer Institute

\section{Source}

National Cancer Institute. Genetically-engineered Immune Cell. NCI Thesaurus. Code C154231.

Any autologous or allogeneic immune cell that has been genetically modified. 